\title{
Introduction
}

\section{Contribution to the Process of Unification of European Private Law}

\author{
Inmaculada Herbosa Martínez \\ Profesora Titular Derecho civil. Universidad de Deusto \\ inmaculada.herbosa@deusto.es
}

doi: http://dx.doi.org/10.18543/ced-61-2019pp23-26

\begin{abstract}
This monographic issue includes several papers related to some questions of Private Law, which are addressed, mainly, from the perspective of European Law but also of Comparative Law. The subjects are diverse and, apparently, without connection, since some address issues related to the new social reality in which we live, related to the information society and unfair business practices; and others deal with traditional institutions of Civil Law, such as prescription, which is subject to review. All of them, however, have a common feature, which is the dogmatic and practical interest of the matters dealt with, and their contribution to the unification, understood in a broad sense, of European Private Law.

Keywords: Europeanization of Private Law, unification of Private Law, electronic commerce, data protection, digital document, unfair commercial practices, extinctive prescription.
\end{abstract}

Nowadays, the penetration of the so-called European and International Law into the internal systems of Member States is beyond doubt. The task of academics is no longer to give notice of it, as is obvious, but to study the new challenges posed by this discipline. When we speak of European Private Law we refer, logically, to the binding instruments and academic texts through which the desirable harmonization in the field of the European Union is sought. Among these are initiatives as meritorious as the Principles of European Law or the Draft Common Frame of Reference, qualified by some authors, without incurring exaggeration, as the most colossal work carried out after the Digest.

In addition, the contribution of academics to all this process of Europeanization and internationalization is worth mentioning. Indeed, they address and solve problems, which can be described as universal, using the science of Comparative Law as understood by SALEILLES, different from the comparative method. This approach implies going back to the foundation of each institution, understanding the features of Private Law of 
the states and, through a process of abstraction, establishing the common features that underlie European laws (at least that of those taken into account in the aforementioned abstraction process).

Certainly, this "Law" does not properly constitute a common Private Law, since it does not come from a European institution nor has it been compiled nor systematized by academics. But it allows to give new solutions to old problems on the basis of common general principles that underlie a concrete regulation, which contribute, by other means, to the unification of Private Law.

This volume contains works on different matters of Private Law, which respond for the most part, to the first of these approaches. However, all of them pay attention to the process of unification of Private Law at a European level in the aforementioned broad sense.

Within a first block, a fundamental issue in today's society (the socalled information society) is addressed, which is the one related to "The loss of privacy in electronic contracting". As is known, in the field of the European Union, several instruments have been adopted that deal, separately, with data protection, electronic contracting and the supply of digital contents or services (among them, Directive 2019/770 relative to certain aspects of contracts for the supply of digital content and services). However, none of these instruments deal with the specific problem addressed in the aforementioned work, i.e. the analysis of the mutual interaction of these instruments, and their possible shortcomings, when personal data is put into circulation in the process of contracting goods or services in the digital market. Once provided, the consumer has little control over his data which, in turn, becomes of great value to the trader since this personal information is susceptible to various forms of treatment (profiling, behavior studies or resale of data to third parties). In this context, the user's contractual control measures on the permissions granted to the trader for the data treatment are analyzed; in particular, in the contract for the supply of digital content in exchange for personal information, which falls within the scope of application of the aforementioned Directive 2019/770.

Also in the field of digital environment, a second work deals with the concept of "written document" in European Private Law, and as a consequence, the concept of electronic document in relation to the broader concept of digital document on the basis of the provisions of Regulation 910/2014, of July 23. Taking as a basis a typical distinction of the Italian Law between written documents and mechanical reproductions, it is concluded that in European Private Law any definition of "written document" must be understood as mere representation or reproduction of words in visible form, since expression includes any communication that involves the memorization of its own content. In favor of this argument 
the broad definition established by the Unidroit Principles is used, comprehensive of any representation of facts stored in durable media through reproducible recordings by mechanical means, provided that they are used as a declaratory means of will.

A third work, related to the Directive 2005/29/EC on unfair commercial practices, deals with the remedies or individual actions available to consumers who, as a consequence of an unfair practice, have signed unwanted contracts or wanted only in part. Bearing in mind that the regulation of these measures has been entirely left to the Member States, there are major divergences between them: while some have foreseen ad hoc solutions, very different from each other, others apply, with some nuances, general remedies of Law of Contracts. This paper questions whether, despite this, the application of other Directives $(93 / 13 / \mathrm{CE}$, 1999/44/EC 2011/83/EU) adopted in the field of consumer protection, which interact with the discipline of unfair practices, allow to apply harmonized and effective protection measures within the European Union. And, in any case, if the principle of good faith could be used to achieve this result.

From the second approach to which we have referred above, a fourth work deals with the extinctive or liberatory prescription. This work involves a deep reflection on the prescription, which not only enjoys the "spell" attributed by the author, but is also inherent in any legal system since it is unimaginable that any claim is not subject to a time limit. Nevertheless, it is not an easy institution either in its dogmatic configuration or in establishing differences with the caducity. In addition to a general overview of this civil institution, the work tries to find out the ratio to which a concrete term of duration responds and, previously, how the legislator's option of having set different terms of duration instead of a single term can be explained. This analysis is based on European texts and others of broader scope, such as the Unidroit Principles, as well as the regulation of this institution in different countries of the European Union, from which common principles and features are extracted for a dogmatic reconstruction of this figure.

\section{About the author}

Inmaculada Herbosa Martínez is Professor of Civil Law at the University of Deusto. He teaches in different subjects in Private Law, among them European Contract Law. Visiting professor at Boston College, Georgetown, Royal College of Complutense at Harvard, and London School of Economics, among other foreign universities. She has been 
Associate Dean for academic affairs, postgraduate studies and research at the Faculty of Law at the University of Deusto. With research merits recognized by the National Commission on this matter has been part of different research teams of the University of Deusto. Currently she is a member of the team «European Integration and Patrimonial Law in a global context». She is the author of four monographs, numerous publications in collective works and articles in specialized journals, as well as the main researcher of several projects. 


\section{Derechos de autor}

Los derechos de autor (para la distribución, comunicación pública, reproducción e inclusión en bases de datos de indexación y repositorios institucionales) de esta publicación (Cuadernos Europeos de Deusto, CED) pertenecen a la editorial Universidad de Deusto. El acceso al contenido digital de cualquier número de Cuadernos Europeos de Deusto es gratuito inmediatamente después de su publicación. Los trabajos podrán leerse, descargarse, copiar y difundir en cualquier medio sin fines comerciales y según lo previsto por la ley; sin la previa autorización de la Editorial (Universidad de Deusto) o el autor. Así mismo, los trabajos editados en CED pueden ser publicados con posterioridad en otros medios o revistas, siempre que el autor indique con claridad y en la primera nota a pie de página que el trabajo se publicó por primera vez en CED, con indicación del número, año, páginas y DOI (si procede). Cualquier otro uso de su contenido en cualquier medio o formato, ahora conocido o desarrollado en el futuro, requiere el permiso previo por escrito del titular de los derechos de autor.

\section{Copyright}

Copyright (for distribution, public communication, reproduction and inclusion in indexation databases and institutional repositories) of this publication (Cuadernos Europeos de Deusto, CED) belongs to the publisher University of Deusto. Access to the digital content of any Issue of Cuadernos Europeos de Deusto is free upon its publication. The content can be read, downloaded, copied, and distributed freely in any medium only for non-commercial purposes and in accordance with any applicable copyright legislation, without prior permission from the copyright holder (University of Deusto) or the author. Thus, the content of CED can be subsequently published in other media or journals, as long as the author clearly indicates in the first footnote that the work was published in CED for the first time, indicating the Issue number, year, pages, and DOI (if applicable). Any other use of its content in any medium or format, now known or developed in the future, requires prior written permission of the copyright holder. 